\title{
The Impact of Forced Removals on Place Names in the Northern Part of the Limpopo Province, South Africa
}

\author{
Nelson Mbulaheni Musehane \\ University of Venda, Thohoyandou, South Africa
}

\begin{abstract}
Forced removals in 1913, 1936, and 1968 have impacted immensely on place names in the Far Northern Transvaal, currently called the Limpopo Province in South Africa. These forced removals have a history which one should learn from. This paper seeks to investigate the impact of removals of communities from one place to another in the far Northern Transvaal. The paper investigates, will focus on the period before and after the apartheid years (1948-1994). The place names to or from which the people were displaced have a history, positive and negative. The latter has resulted in pain and frustrations for the removed inhabitants. The research will be accomplished by analysing place names in published and unpublished documents. The respondents who know the history of the places in the far Northern part of the Limpopo Province will be contacted with the view of establishing the impact that the removals have influenced place names. Qualitative method will be used. The data will be critically analysed and verified to establish the desired result. The research will contribute immensely in the preservation of the distorted history of these place names that the communities living in those regions today know. This could one day restore the past history of the communities in the far Northern Province.
\end{abstract}

Keywords: impact, forced removals, place names, Northern part of the Limpopo Province and South Africa

\section{Introduction}

Before one attempts to discuss the issues in this article, it will be appropriate to define the main concepts in this article. Procter (1985) defined removal as: (an) act of removing. Sometimes removal is unpleasant, when it brings misfortune and it is good when it brings one to a fortune, just like one getting in a new house (p. 935). On the other hand the Oxford Advanced Learner's Dictionary (2005) defined it as: "The taking away from a particular place” (p. 1234). Procter (1985) defined force as: "To make (an unwilling person or animal) do something; drive- to push using force” (p. 436).

Forced removal is done against one's will. It may be a forced relocation to a job in another city. It may be the use of physical force, Oxford Advanced Learner's Dictionary: International Student Edition (2005, p. 581).

From the above definitions, one can conclude that forced removal is a way of forcing things to be displaced. This can be physical. It can also refer to creating conditions that compel one to move from one place to another.

In folklore studies, there is often a perceived connection between bearing a name and existing. The name comes into being after an event has taken place or in commemoration of something. Asher and Simpson (1994)

Nelson Mbulaheni Musehane, professor, School of Human and Social Sciences, University of Venda. 
described the cultural practices in naming as follows: "This dialectic of the individual as (a) socially constituted ,and (b) self-conscious and self-directing lies behind most dilemmas of identity and their analysis in social sciences” (p. 2675).

We have three recognized categories of names for geographical entities. Musehane (2008, p. 59) maintained that a name is a word used to identify a person or a place. Place names, strictly defined, are geographical names. However, they are usually applied to natural or social features, at scales varying from local to regional, which have meanings for the original or subsequent occupants. Their origins may extend back. In time, they may be derived from diverse linguistic roots and they form part of cultural, legal and linguistic history of a country. While changes and modifications do occur, this in turn illustrates the evolving culture of an individual country (Rossi, 1965).

\section{Theoretical Framework}

Mushiane (1999, p. 12) quoting Simpson (1997) contends that "Place names reflect historical influence, place names are frequently accepted into the language of a new population” (p. 95). According to this description, place names may have a historical back ground. By historical background we mean the name given according to what happened in the past.

There are many places in the Northern part of the Limpopo Province where communities were forcefully removed to other places. This forced removal was done in order to give space to the white folks who wanted to farm and be separate from black people. The researcher will analyse these place names from published and unpublished works of other scholars; consult with the inhabitants, self-knowledge of the areas and places, to find out the impact forced removals had in the naming of places in those areas. In addition, selected respondents who know the history of those places will be contacted to counter-check data and ascertain the validity of the data received from the literatures and the respondents.

\section{Causes of Removal}

There are many causes that displace man in life. Man can be termed a displaced person, referring to a person who has been forced to leave his/her own country or place. He/she can be displaced by legislation, societal causes, compulsion of starvation, and wars, etc.. Place names can be classified based on the cause(s). There are those names that are inspired (legal causes) by apartheid experiences as well as those inspired by post-apartheid events, like CODESA (Convention for a Democratic South Africa) and RDP (Reconstrucción and Development Programme) houses.

\section{Legal Causes of Removals}

There are many acts which/that were promulgated by the Apartheid Government of South Africa, starting from 1913 to 1948, even before apartheid laws were passed. There are also apartheid and post-apartheid laws. The Nationalist Government of South Africa enacted laws to define and enforce segregation. This is what makes South Africa's apartheid era different from segregation and racial hatred in other countries. When the National Party came into power in 1948, it formalised this segregation through legislation. The acts are as follows:

(1) Prohibition of Mixed Marriages Act of 1949.

The act prohibited marriages between white people and people of other races. Between 1946 and the 
enactment of this law, only 75 mixed marriages had been recorded, compared with some 28,000 white marriages. It caused couples to be separated from each other.

(2) Immorality Amendment Act of 1950; amended in 1957.

The act prohibited adultery, attempted adultery, or related immoral acts (extra-marital sex) between white and black people. It forced people of colour to move from areas proclaimed as "White areas".

(3) Population Registration Act of 1950.

Led to the creation of a national register in which a person's race was recorded. A Race Classification Board took the final decision on what a person's race was, where it was disputed. It displaced people of different races from one place to another.

(4) Group Areas Act of 1950.

It forced physical separation between races by creating different residential areas for different races. It led to forced removals of people living in "wrong” areas, for example coloured people living in District Six in Cape Town.

(5) Suppression of Communism Act of 1950.

It outlawed Communism and the Communist Party in South Africa. Communism was defined so broadly that it covered any call for a political change. Communists could be banned from participating in political organisations and restricted to a particular area. Those who participated in this practice were displaced from one place to another for fear of "contaminating" other people with these communist beliefs.

(6) Bantu Building Workers Act of 1951.

It allowed black people to be trained as artisans in building trade, something previously reserved for Whites only. However, they were expected to work within an area designated for Blacks only. The act made it a criminal offence for a black person to perform any skilled work in an urban area. Those who were discriminated against were forced to be displaced from one area to another.

(7) Separate Representation of Voters Act of 1951.

This act, together with the 1956 amendment, led to the removal of Coloureds from the common voters' roll. This caused dissatisfaction among the Coloureds, and some were displaced to other areas.

(8) Prevention of Illegal Squatting Act of 1952.

The act gave the Minister of Native Affairs the power to remove Blacks from public or privately owned land to establishment camps to house these displaced people.

(9) Bantu Authorities Act of 1951.

The act provided for the establishment of black homelands and regional authorities, and the homelands abolished the Native Representative Council. This led to Black races to stay separate from all other people and they were forcefully displaced.

(10) Native (Abolition of Passes and Co-rdination of Documents) Act of 1952.

Commonly known as the Pass Laws, this ironically named act forced black people to carry identification with them at all times. A pass included a photograph, details of a place of origin, employment record, tax payments, and encounters with the police. A black person was to produce a pass when required to do so by the police. No black person could leave a rural area for an urban one without permission from authorities. On arrival in an urban area a permit to seek work had to be obtained within 72 hours. This act controlled the movement of black people and forced them to be displaced to other areas. 
(11) Native Labour (Settlement of Disputes) Act of 1953.

Prohibited strike action by Blacks. Those who feared arrest were fled to other areas.

(12) Bantu Education Act of 1953.

The act established a Black Education Department in the Department of Native Affairs which compiled a curriculum that suited the nature and requirements of the black people. The author of the legislation, Dr. Verwoerd (then Minister of Native Affairs, later Prime Minister) (1961-1963), stated that its aim was to prevent Africans from receiving an education that would lead them to aspire to positions they would not be allowed to hold in society. Instead Africans were to receive an education designed to provide them with skills to serve their own people in the homelands or to work as labourers for Whites. This made the black people remain in their rural areas.

(13) Reservation of Separate Amenities Act of 1953.

The act forced segregation in all public amenities, public buildings, and public transport with the aim of eliminating contact between Whites and other races. Consequently, "European Only" signs were erected. The act stated that facilities provided were for different races: "Europeans only" and "Non-Europeans only". The act stated that facilities provided are different.

(14) Native (Prohibition of Interdicts) Act of 1956.

The act denied black people the option of appealing to the courts against forced removals

(15) Bantu Investment Corporation Act of 1959.

The act provided for the creation of financial, commercial, and industrial schemes in areas designated for black people. This led to Blacks not to living in areas meant for Whites, because the act would not assist them financially, commercially, or with industrial schemes.

(16) Extension of University Education Act of 1959.

The act put an end to black students attending "White" universities (mainly the universities of Cape Town and Witwatersrand) and created separate territories and institutions for Whites, Coloured, Blacks and Asians.

(17) Promotion of Bantu Self-Government Act of 1959.

The act classified black people into eight ethnic groups. Each group had a Commissioner-General who was tasked with developing a homeland for each group, which would be allowed to govern itself independently without White intervention. This led to Blacks staying within their ethnic group.

(18) Urban Bantu Councils Act of 1961.

The act created Black councils in urban areas that were supposed to be tied to the authorities running related ethnic homelands. This made people attached to their homeland.

(19) Bantu Homeland Citizens Act of 1970.

The act compelled all black people to become citizens of the homeland that corresponded with their ethnic group, regardless of whether they had ever lived there or not, and took away their South African citizenship. This led to the people being displaced to the ethnic group to which they belonged (Retrieved from http:p//Africanhistory.about.com/library/blsalaws.htm).

Various segregation laws were passed before the Nationalist Party took complete power in 1948. Probably the most significant ones were The Natives Land Act, Act, No. 27 of 1913 and the Natives' (Urban Areas) Act of 1923. The former made it illegal for Blacks to purchase or lease land from Whites, except in black reserves. This 
restricted Black occupancy to less than eight percent of South Africa's land. The latter acts laid the foundation for residential segregation in urban areas. This acts contributed to the forced removals that occurred in South Africa before and apartheid (1948-1994). This made people unhappy. They responded through naming, songs, etc.

\section{Societal Causes of Removal}

Some of the conditions of removals are societal in nature. When a young boy and girl get married, the couple is expected to stay with the extended family. Because of societal problems encountered in the family when they get married, sometimes they have to go to an area where they would stay together as husband and wife, alone.

Zwa vhavhili "for two only". There are two areas called Zwa vhavhili in the Vhembe District Municipality. One of the areas is found at Lwamondo, situated to the north of the road to Louis Trichardt, Route 524 from Zwikwengani (the Sisal plots) to Rhema Kingdom Life Church. The respondents interpreted the area as a place that is currently settled by newly-wed couples, i.e., brides and bridegrooms. It is alleged that a couple was forced to move from their parents' homes by changing in societal life to come and settle there as husband and a wife.

The place is named Zwa vhavhili "for two only", because it is mostly populated or inhabited by newly-weds'. Although some of the couples are not young, most of them are young couples. Secondly the generation of today does not favour staying with the in-laws. This is why in-laws are not welcome at Zwa vhavhili.

The second place called Zwa vhavhili "for two only" is on the southern side of the Thohoyandou Government Offices. The place is named Zwa vhavhili "for two only", because one normally finds lovers on the lawns of the park. It is mostly a meeting place for partners or prospective partners; hence, the place is called Zwa vhavhili "for two only". The prospective partners are "forced" by love to be together although the place was not named as a result of forced physical removals.

Golgotha "biblical place of Golgotha". It is an area west of Khoroni Hotel between the University Road and the Main Road from Sibasa to Makhado. It is a place where the Tshiluvhi people lived before the establishment of the Thohoyand्रou Town. It is a place where the Tshiluvhi people lived before they were forcefully moved to give way for the establishment of the town. There is a grave yard on the west of the road going to Sibasa. Around the grave yard there is an extension of the Thohoyandou Location. The grave yard is surrounded by the houses of Thohoyandou location. The graveyard was for the residents who resided in the area of Tshiluvhi. These former residents have left some graves behind. The place has been named Golgotha to emulate what happened in Biblical times when Jesus Christ was crucified at Golgotha, according to The Holy Bible, King James Version. The place Golgotha loosely means a place of the skull or graves.

The following scriptures of the Bible summarise the issue to which this place is being equated with:

"And when they were come unto a place called Golgotha, that is to say, a place of the Skull" (Mathew $(27: 33))$.

The same matter has been recorded in Mark (15:22), Luke (23:32), and John (19:17-18) where the issue of a graveyard called "a place of a skulls” is described, which is called, in Hebrew, Golgotha. When they crucified him, and the two other with him on either side.

The place is named Golgotha to mean that it is near the grave yards. It can also suggest that it is a place where the Tshiluvhi people were crucified by being forcefully moved. In addition, in Khubvi, there is street called Golgotha. If one takes this street from the main road from Sibasa to Mutale, in the eastern side, one will ultimate 
end at the grave yard. The author's informant stated that the street was named Golgotha, because it ended at the local graveyard.

Tana-hi-wexe (come personally). This is an informal settlement situated in the Thulamahashe Township in Bushbuck Ridge. When contract workers from the former Gazankulu Public Works erected tents during the construction of the local dam, local women used to visit the settlement in search of men. The place was named Tana-hi-Wexe, telling women from the neighbouring places of Thulamahashe that females are attracted to this place to come personally, and not compelled. The contractors were happy, because back home they were happily married and blessed with children. Chauke (2004) reiterated that the name was given to this place to communicate with the local women that they should come to the tents of their own accord.

Tana na Xixevo "bring relish". This is a settlement of low cost RDP houses found in Nkuzana. The location is comprised mainly of spinsters. Because it is mostly inhabited by unmarried females, most of them are poor and live from hand to mouth. The inhabitants instruct males who often prefer to visit this place in search of mistresses to bring some relish. When a man finds a woman, his role is to bring some meat as relish, because the female can only provide a bag of maize-meal. It is clear in this name that the words uttered by the females living in this settlement. It implies that what the men need to is not a bag of maize-meal. Hence, Tana na xixevo "come with the relish”.

\section{Place Names Inspired by Apartheid Removals}

Sokotenda or Sokoutenda “just agree”. During 1965 to 1968 people living on the northern part of road Route 523 from Sibasa to Wyliespoort were forced to relocate. This is the road which passes through Ngovhela village to Wyliespoort. Another name is Besekuwe, bada ya Ngovhela, meaning "Besekuwe-a road to Ngovhela". People were forcefully removed and the government of the day wanted them to resettle on the southern side of the road. The people were removed to give space for the development of a White suburb. The late Mr Lawrence Takalani, who was a member of residents to be removed, stated that they disagreed with the idea, because they had maize fields and fruit trees. The pressure was intense for the people. However, they eventually succumbed to the pressure and went to a place earmarked for residence. It was named Sokotenda or Sokoutenda, meaning "just agree" to express their reluctance to the forced removal. To this day, the place is still known as Sokotenda or Sokoutenda. The area stretches from the old Lukoto Bus depot to Thomboni dza Tshiwamisevhe.

Diambele "speak for oneself". This place is in Tshakhuma. It is on the eastern side of Barota Banana farm.

Young residents of Tshakhuma could erect their houses there. The available area on the western part of Tshakhuma was earmarked for banana fields. Tshakhuma residents did not have additional space for residences. The western side was the Barota farm and the southern side was the road Route 524 from Louis Trichardt (Makhado) to Thohoyandou. Seeing that the residents did not have a place earmarked for residence, the respondents informed me that they engaged the authorities into a discussion, asking for a place to live. It was difficult, because of the scarcity of residential land. The authorities acceded to the request, and they were given that place. It was named Diambele literal meaning that the space was granted after they had negotiated with the authorities to be granted permission to settle on the land for residential purpose.

Gandlanani “pack firmly in one place”. This place is situated about five kilometers from Malamulele Township. The name was given to the village in reaction to the forced removals from their ancestral place, where 
they used to occupy vast pieces of land. According to Chauke (2004, p. 127), gandla means to pack firmly in one place. The name was given, because people were forcefully relocated to this place from their ancestral place. The name indicates that people were densely resettled on a very small piece of land. In reacting to the dissatisfaction, the residents called it Gandlanani "pack firmly in one place” to indicate to the government of the day that they were dissatisfied with this action. The residents gave the name in order to register their dissatisfaction to the government of the day.

Ha Tshama "we are staying". This is an area found on the eastern side of Giyani Township. According to Chauke (2004, p. 128), it is a village which was under the leadership of three headmen, namely, Makosha, Risinga, and Munguni.

According to Chauke (2004, p. 128) the village was established after forced removals and relocation of people in terms of the Urban Areas Act.

The place is situated where Giyani is today. It was named following the name of the leader Risinga. When the residents of Risinga were forced to leave their ancestral area, it was agreed that a new area would be allocated to them for settlement. In the process of relocation, Risinga residents were surprised to learn that they would share their newly acquired area with the subjects of Makosha and Munguni.The Risinga residents reacted to the arrangement and vowed to stay and not to move to any place, hence, the name Ha tshama, literally meaning "we are staying here and not going anywhere else".

The residents had been informed that they should abandon the newly-acquired area and relocate to Homu Block 14 C, some 15 kilometers to the east.

The proposal was met with great resistance and the residents indicated in no uncertain terms that they were no longer prepared to move, hence, the name Ha tshama.

Giyani "Dance after happiness". Giyani is the capital town of the former Gazankulu homeland. It is situated where the Madzivhaniombe Mountains in the former Vendaland were. It was a place where the Vatsonga communities were moved to establish a "town". Chauke (2004) maintained that the verb giya "to dance by stumping” suggested it was a place where the Vatsonga succeeded in re-grouping as a community after they had been moved from different areas to settle in Giyani. They were happy, because they had finally managed to form their own Vatsonga community. The town is a symbol of happiness after the Vatsonga community came to stay together after they had been stayed scattered among other nations without land of their own.

It was recognized as the capital town of the Vatsonga community during the homeland system.

Hence, Mr. S. J. Khosa, a Xitsonga musician, composed a song called Giyani, meaning "the dance after happiness".

Hluphekani "place of suffering”. This is an informal settlement located southeast of Giyani Town. It was established for Mozambican refugees. The name is self-explanatory, because the inhabitants were in a state of abject poverty. Chauke (2004) maintained that "the place looks smells and sounds like a typical ghetto. There is no fresh drinking and running water. Sunrise is interpreted as another day of suffering” (p. 134) there, hence, Hluphekani, derived from the verb -hlupheka (to suffer).

Tshemba-nenge "trust the legs". Mozambicans were once invaded by the Nguni warriors. The Nguni conquerors forced the Vatsonga to flee. Subsequently, they had to walk long distances to South Africa. They encountered many hardships along the way and some died of starvation, disease, and brutal attacks by wild 
animals in the national park. Those who survived and succeeded in reaching South Africa, the respondents reported, were resettled in a place called Tshemba-nenge "trust the legs", to show that those who had travelled long distances overcame despair and tribulations by using their feet to travel long distances. The name shows that it is a place settled by refugees from war-torn Mozambique. Themba-nenge means that those who trusted their strong legs to carry them walked from Mozambique to South Africa for a better life.

Phuphuledzhi in Tshiguvhu "feel or grope over with the fumble in Northern Sotho dialect". This is an area at Mulima bordering Nthabalala Tribal land. The respondents said that communities were forcefully moved to the place which did not have electricity. When one gets into a house at night, one has to phuphuledza, meaning "to feel or grope over with the tips of the fingers; fumble for a matchbox to light the lamps", hence, the place was given the name Phuphuledzhi in Tshiguvhu a dialect of Northern Sotho. This was to point to the authorities that the place was not conducive for human settlement, because it did not have electricity.

\section{Place Names Influenced by Post-Apartheid}

\section{Sihlalangenkani "We Stay with Contention"}

This is an area in Musina. The Musina Municipality had earmarked the area for low-cost RDP houses. While the municipality was still waiting for the developer to arrive, the residents moved to the areas to occupy the space and not wait for the contractor. The residents resisted the project. Some of the inhabitants had been waiting for a long time for RDP houses. Instead of going to another place to settle, so that development could start, they vowed to stay by force unless they were allocated RDP houses.

\section{Zwinarini "At the RDP Houses"}

"Zwinnarini" is loosely meant a place where low-cost RDP houses are found built in large numbers. The developing contractor who won the tender to build the houses at Miluwani near Thohoyandou town was Nare Construction (Pty). Because the construction was done by Nare, the Vhavenda called the place zwinarini, meaning a place where Nare low-cost RDP houses were built.

These RDP houses are found on the western side of Thohoyandou. In all places where these low-cost RDP house are found in large numbers, the Vhavenda call them zwinari and the place where the houses are found is called zwinarini.

\section{Khodesa "CODESA"}

This is a place in Ha Mutsha. The author's respondents said that the place was given the name, because it was through negotiation that the residents were given the place. This was to emulate the CODESA, which was held at Kempton Park, when the ANC (African National Congress) and the South African Apartheid Government entered into negotiations for a democratic South Africa after a fierce fighting:

Nineteen groups were represented at CODESA, including the South Africa Government, the National Party, the African National Congress, the Inkatha Freedom Party, the Democratic Party, the South African Communist Party, the South African Indian Congress, the Coloured Labour Party, the Indian National People's Party, the Solidarity Party, and the leaders of the nominally independent Bantustans of Transkei, Bophuthatswana and Ciskei. (Retrieved from http://en.wikipedia.org/wiki/Negotiations to end apartheid in South Africa)

Some of the name places not discussed above which reflect the cultures of the communities in the northern part of the Limpopo Province are the corrupted place names such as Sihambe "we should leave”, Thembaluvhilo 
"trust your speed" and Phulamulenze "roll up your socks", showing that the place is frightening and people should run when they reach that place.

\section{Conclusions}

From the preceding discussion one can say that place names practices reflect the politics of the day, background of the communities “commemoration and religious" history. It is indeed true what Chauke (2004) maintained, that:

Forced removals had a social influence on place names such as Zwa vhavhili, Golgotha, Tana hi wexe, and Tana na xixevo. In addition, there are those names that were politically influenced or that were inspired by the apartheid experience, like Soko (u) tenda, Diambele, Gandlanani, Ha tshama, Giyani, Hluphekani, Tshemba-nenge, and Phuphuledzhi. Names that were inspired by post experiencing include Sihlalangenkani, Zwinarini, and Khodesa "CODESA". The structure of the place names varies according to the language of origin of the names. It was noticed that the place names discussed in this paper reflect a spectrum of emotions, reminding us that they were and are used daily by human beings who resided in those places. (p. 116)

\section{References}

Asher, R. E., \& Simpson, J. M. Y. (1994). The encyclopedia of language and linguistics (Vol. 3). Oxford: Pergamon Press.

Chauke, M. T. (2004). Aspects of naming in Xitsonga (Unpublished thesis of D. Lit in Xitsonga, Turfloop Campus, University of North).

Musehane, N. M. (2008). Name Change: A case study of indigenous Africans of South Africa. Southern African Journal for Folklore Studies, 18(2), 59-70.

Mushiane, M. D. (1999). An investigation into place naming with reference to Tshivenda (Unpublished B.A. honours dissertation, University of Venda).

Oxford advanced learner's dictionary 2005-International student (7th ed.). (2005). Oxford: Oxford University Press.

Procter, P. (1985). The Longman dictionary of contemporary English. Great Britain: Longman.

Rossi, E. (1965). On promotion of children's and adolescents'social. UK: Claudio Baraldi

Simpson, J. A. (1979). The Oxford English dictionary. New York: Teacher College. 